\title{
INNOVATIVE ACTIVITY OF ENTERPRISES IN THE PERIPHERAL REGION
}

\author{
Magdalena Anna Zwolinska-Ligaj ${ }^{1}$, PhD; Mieczyslaw Adamowicz' ${ }^{2}$ Prof. \\ 1,2 Pope John Paul II State School of Higher Education in Biala Podlaska
}

\begin{abstract}
The purpose of the work is to characterize the state of innovative activity of enterprises operating in the peripheral region, as well as to define the prospects for its increase with an indication of the most important barriers of this activity. The work presents the results of empirical research carried out in the Lublin province on a sample of 147 enterprises. The study used the diagnostic poll method using an interview questionnaire. The research allowed for a positive verification of the hypothesis about the existence of a small group of enterprises focused on development in the studied area, active in the area of introducing innovations, noticing the need to implement them and capable of overcoming numerous barriers in this process. Limitations of innovation are more often noticed by entrepreneurs active in the area of the innovation implementation. The main barriers limiting the innovative activity of the assessed enterprises include financial barriers. Barriers related to limited access to knowledge in the innovation process against the background of financial barriers are not very important.
\end{abstract}

Key words: innovations, rural enterprises, factors and barriers to innovation, effects of innovative activity. JEL code: R11

\section{Introduction}

The research undertaken so far on the conditions and possibilities of stimulating innovation processes in peripheral regions focused on their low innovative potential and unfavourable, permanent barriers for innovation. These factors led to deepening disproportions in the level of development of peripheral regions in comparison to the regions considered as development centres.

In consideration of the explanation of the causes of developmental problems of peripheral regions, the authors refer primarily to the concept of geographical proximity, accessibility and agglomeration effects (agglomeration economies), which do not manifest themselves in peripheral regions, limiting their innovation. In literature, the proximity and accessibility are emphasized as crucial for shaping economic, social and institutional relations on a local and regional scale that are the foundation for stimulating innovation (Copus A., Skuras D., Tsegenidi K., 2008). The role of the social factor in shaping the pace and scale of innovation processes is an important thread of the discussion (Rodriguez-Pose A., 1999).

In the case of peripheral regions, one can indicate a certain specificity of the course of innovation processes in enterprises. Enterprises and entire industries implement mainly incremental innovations. Companies from peripheral regions need to improve the process of learning and start cooperating with various entities in order to be able to use external knowledge from distant sources in their internal innovation processes (Isaksen A., Karlsen J., 2016). However, most entrepreneurs rely mainly on their own initiative and communicate or cooperate with a small number of entities (Innovation Systems..., 2005).

In addition to the limited access to knowledge, the innovative activity of entrepreneurs in peripheral regions largely limits the significant costs of innovative activity and the level of indebtedness. In turn, these attitudes are stimulated by such factors as technical qualifications of employees, presence on foreign markets and the scale of employment (Coronado D., Acosta M., Fernandez A., 2008).

However, as shown by the results of research carried out in European regions, the location is not the sole factor explaining the state of activity of enterprises in the field of innovative activity. The research results show that in regions with conditions highly unfavourable to innovative activity, 
which include peripheral regions, it is also possible to find examples of enterprises and territories advanced in terms of the state of innovation (Varis M., Littunen H., 2012, Smallbone D., North D., Kalantaridis C. 1999, North D., Smallbone D., 2000). Thus, geographical proximity does not have to be a necessary or a sufficient condition for innovative processes resulting from the availability of knowledge. The importance of geographic proximity should also be assessed together with other dimensions of closeness, such as cognitive and organizational proximity, resulting from embedding in local institutions (Boschma RA, 2005, Fitjar RD, Rodríguez-Pose A., 2011, Araujo L., Silva S., Teixeira A., 2013).

Companies operating in rural peripheral regions with difficult conditions may be subject to adaptation processes, while in practice specific environmental conditions may lead to different innovative patterns (De Noronha Vaz, MT, Cesario, M., \& Fernandes, S. 2006). Successful adaptation to local conditions can rely on proactive product and market development in order to overcome the limited size and scope of local markets, adopt a laborious development path to exploit the potential benefits of remote rural labour markets and relatively low subcontracting (Smallbone D. North D., Kalantaridis Ch., 1999). Regarding the limitation of access to knowledge, it can be noticed that companies implementing innovations compensate for the lack of access to local knowledge transfers by making cooperation on a wider scale. It is characteristic for companies with strong internal capabilities to compensate for the lack of local knowledge exchange with cooperation, while companies with weaker internal capabilities depend more on the regional knowledge infrastructure (Grillitsch M., Nilsson M., 2014). It is possible to find examples where the need for external help in obtaining knowledge and information necessary to undertake innovative activity makes companies find it wherever it is, regardless of geographical limitations. (North D., Smallbone D., 2000).

Implementation of innovations in the peripheral region requires the entrepreneurs to undertake cooperation with various types of partners. In particular, the factor conductive for innovation is the development of international contacts in the field of innovation, including the one with customers, suppliers of equipment, materials, components or software, consultants, laboratories or private research and development institutions (Fitjar R.D., Rodríguez-Pose A., 2011, Araujo L ., Silva S., Teixeira A., 2013). It is characteristic that the implementation of more advanced innovations depends on cooperation with universities and other subjects in the field of science. In turn, when implementing less advanced innovations, enterprises cooperate to a greater extent with business support entities - Knowledge Intensive Business Services (KIBS). The cooperation of enterprises with KIBS is perceived as a factor reducing regional inequalities (Todtling F., Lehner P., Kaufmann A., 2009, Muller 1999). Strengthening the innovation of enterprises in rural areas is one of the basic factors stimulating processes of economic development and creating jobs in these areas. According to the research results, the innovative production companies have the best opportunities for creating jobs in the rural economy (North D., Smallbone D., 2000, Drejer, I., \& Vinding , AL 2005). Conclusions from other studies indicate that factors such as the collocation of companies belonging to highly specialized industrial niches and the pro-activity of local knowledge institutions (Virkkala S., 2007) as well as public subsidies for innovations are important for acquiring knowledge in peripheral regions (Varis M. , Littunen, H., 2012).

The system of entrepreneurship and innovation centres in the Lublin Voivodeship can be considered as well developed and available to potential clients; however, the quality of the institution's offer requires constant improvement (Płoszaj, A. 2012). The activity of local authorities 
in case of support of innovation of local economies also requires strengthening (Zwolinska-Ligaj, M., Adamowicz, M. 2017). In rural areas, the chances of improving innovation are related to the strengthening of the role of such rural development instruments as Local Action Groups (LAGs) implemented under the Leader Programme (Guzal-Dec D., Zwolinska-Ligaj M., 2017a, 2017b).

The research process included formulation and justification of the research problem concerning the condition and determinants of the enterprises' innovation activity revival in the studied area, formulation of the hypothesis, identification of variables, selection of methods, development of research tools and conducting field research, statistical and quantitative development of results, and finally - theoretical analysis of the obtained material and deriving conclusions. Innovative activity was tested according to the types of innovations compliant with the OECD guidelines (Oslo Manual ..., 2005).

The purpose of the work is to characterize the state of innovative activity of enterprises operating in the peripheral region, as well as to define the prospects for its increase with an indication of the most important barriers to this activity. A hypothesis about the existence of a small group of enterprises focused on development in the studied area, active in the area of introducing innovations, perceiving the need to implement innovations and capable of overcoming numerous barriers in this process was formulated. Enterprises that do not undertake innovative activities reside in the existing markets, being unable to introduce changes of a developmental nature due to the difficult economic situation and high costs of innovative activity or they do not see the need for changes.

Empirical research was carried out in two districts of the Lublin Province (Pulawski and the Bialski district) ${ }^{1}$. In each of the districts, seven municipalities were selected for the study taking into account their degree of development and the specificity of their differentiated location in the district area and the nature of their economy. In each of the fourteen examined municipalities, based on the REGON register, 10 to 15 companies were selected for the survey2. A method of diagnostic survey with the use of an interview questionnaire addressed to the owners (or managers) of the companies was used as the tool of the research. A total of 147 interviews was collected, including 80 in the Bialski district and 67 in the Pulawski district. The research was conducted from July 1 st to August 10th, 2015. The results of the research were processed using the Statistica 10 Program.

\section{Research results and discussion Characteristics of enterprises}

The enterprises which created the sample, were characterized by well-established market experience. Most of them - $93.9 \%$ - were created after the beginning of the system transformation process - after 1989. The sample consisted mainly of micro and small enterprises. Enterprises with full-time employment of up to 9 persons accounted $62.3 \%$ of the sample, while from 9 to 49 persons $-35.0 \%$. The surveyed enterprises represented only the private sector. These enterprises mostly operated in the form of individual business activities $(60.5 \%)$. Almost every fifth entity $(18.6 \%)$ had the status of a family business.

The surveyed enterprises most often represented the services sector, including such industries as: wholesale, retail trade and repairs $(18.4 \%)$, accommodation and food service activities

${ }^{1}$ The research was financed from the Pope John Paul II State School of Higher Education in Biała Podlaska funds under the statutory research of the Department of Economics and Management.

2 The selection was made on the basis of the municipality type, the number of economic entities in the municipality, the reflection in the sample of the branch structure of the economic operators in the municipality and the highest employment level. 
$(11.6 \%)$, transport and warehouse management $\rightarrow(6.1 \%)$, other services $(22.4 \%)$. In the sector of industrial processing and construction, there were $6.1 \%$ and $15.6 \%$ of entities respectively.

Over half of the enterprises ( $51.7 \%$ ) operated on local markets, including $43.6 \%$ on the regional and/or municipal market. The regional scale of activity concerned $19.1 \%$ of entities, and national - $22.4 \% .6 .8 \%$ of the entities reported their presence on foreign markets. A large group of respondents represented entities with an established market situation. Almost half $(47.6 \%)$ of the surveyed entrepreneurs assessed that the company is in a good and very good economic and financial situation. The average and the bad and very bad grades were formulated by, respectively - $44.9 \%$ and $7.5 \%$ of the respondents. In addition, almost half (46.2\%) noted the development of the company's activity within 3 years of the survey.

\section{Innovative activity}

Despite the fact that a significant group of entrepreneurs noted the development of the company, their overall activity in the area of innovation implementation should be considered as small. In the tested sample, only $16.3 \%$ of enterprises implemented at least one innovation in the period 2010-2014. The most frequently implemented innovations had the character of product innovation, entailing the introduction of new or significantly improved products or services (Table 1).

Product innovations were introduced in the case of $12.9 \%$ of enterprises, whereas in almost half of these enterprises no more than one innovation was introduced. In addition to productoriented innovations, entrepreneurs undertook actions, to a lesser degree, within the process innovations by introducing changes consisting of the introduction of new or significantly improved processes, mainly related to the methods of producing products and/or providing services $(6.2 \%)$. Innovation in marketing was the third area of innovation activity. Entrepreneurs mainly made significant changes in design projects or packaging of products or services (5.5\%). The dimension of innovative activity in the case of which no activity was recorded were organizational innovations related to the implementation of the new methods in terms of operating principles, e.g. quality management systems, the division of tasks and decision-making powers among employees, relations with the surrounding - other enterprises or public institutions.

The image of very low innovation activity in the surveyed group is improved by entrepreneurs' declarations regarding planned innovative activities (Table 1 ). The largest number of respondents $(37.8 \%)$ declared having a product innovation implementation plan. The second important direction of planned innovations was to change the methods of manufacturing products/providing services (reported by $24.5 \%$ of respondents). Other observed directions of innovative activity reported by about $10 \%$ of the surveyed entities included: changes in methods of supporting the processes, significant changes in the design/construction or packaging of products or services, division of tasks and decision-making powers among employees. Despite the lack of involvement of entrepreneurs in organizational innovations so far, they have therefore been accentuated in their plans. 
Implementation status in the period 2010-2014 and declared implementation plans for the selected types of innovations in the studied group of enterprises

\begin{tabular}{|c|c|c|c|c|c|c|c|}
\hline \multirow{2}{*}{ No. } & \multirow{2}{*}{$\begin{array}{c}\text { Type of } \\
\text { innovation }\end{array}$} & \multirow{2}{*}{ Examples of innovations } & \multicolumn{4}{|c|}{$\begin{array}{c}\text { Percentage of enterprises } \\
\text { in which a certain } \\
\text { number of innovations } \\
\text { was implemented }\end{array}$} & \multirow{2}{*}{ 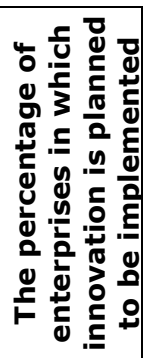 } \\
\hline & & & none & 1 & 2-5 & $>5$ & \\
\hline 1. & \multicolumn{2}{|r|}{ Product } & 87.1 & 6.1 & 6.1 & 0.7 & 37.8 \\
\hline \multirow{3}{*}{2.} & \multirow{3}{*}{$\begin{array}{l}\text { Process- } \\
\text { new or } \\
\text { significantly } \\
\text { improved }\end{array}$} & $\begin{array}{l}\text { methods of manufacturing products/providing } \\
\text { services }\end{array}$ & 93.9 & 4.8 & 1.4 & - & 24.5 \\
\hline & & $\begin{array}{l}\text { methods in the field of logistics and/or delivery } \\
\text { and distribution methods }\end{array}$ & 98.0 & 2.0 & - & - & 7.7 \\
\hline & & methods supporting processes, e.g. accounting & 99.0 & 1.0 & - & - & 10.5 \\
\hline \multirow{3}{*}{3.} & \multirow{3}{*}{$\begin{array}{l}\text { Organization } \\
\text { al - } \\
\text { implementat } \\
\text { ion of a new } \\
\text { method in } \\
\text { the field }\end{array}$} & $\begin{array}{l}\text { of operating principles, e.g. quality } \\
\text { management systems }\end{array}$ & 100.0 & - & - & - & 6.3 \\
\hline & & $\begin{array}{l}\text { division of tasks and decision-making powers } \\
\text { among employees }\end{array}$ & 100.0 & - & - & - & 9.7 \\
\hline & & $\begin{array}{l}\text { relations with the surrounding - other } \\
\text { enterprises or public institutions, e.g. using } \\
\text { subcontracting for the first time }\end{array}$ & 100.0 & - & - & - & 0.7 \\
\hline \multirow{4}{*}{4.} & \multirow{4}{*}{ Marketing } & $\begin{array}{l}\text { significant changes in the design/construction } \\
\text { or packaging of products or services }\end{array}$ & 94.5 & 4.8 & 0.7 & - & 10.5 \\
\hline & & new media or product promotion techniques & 98.0 & 2.0 & - & - & 6.3 \\
\hline & & $\begin{array}{l}\text { new methods in the distribution of products or } \\
\text { sales channels }\end{array}$ & 99.0 & 1.0 & - & - & 4.9 \\
\hline & & $\begin{array}{l}\text { new methods of pricing the products and } \\
\text { services }\end{array}$ & 100.0 & - & - & - & 4.9 \\
\hline
\end{tabular}

Source: authors' calculations based on empirical research

The objectively low innovation activity in the studied group was accompanied by a fairly high self-esteem of the innovative activity of the enterprise against the background of competitive enterprises, where more than half of the surveyed entrepreneurs rate innovative activity as high and very high compared to competitors (Fig. 1).

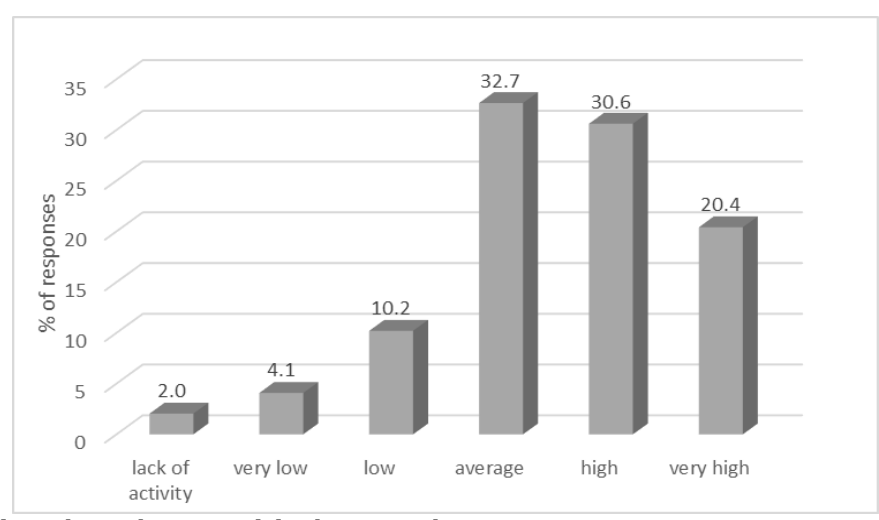

Source: authors' calculations based on empirical research

Fig. 1. Self-evaluation of the company's innovative activity against the background of competing enterprises in the period 2010-2014 ( $\%$ of responses)

Entrepreneurs assessed their activity in the area of studied innovation areas as minimal. However, according to the opinions formulated by the respondents, this area of activity will not constitute a priority in the development of the enterprise. It can be pointed out that there is a 
small gap between the current and future - desired - role of innovation in the enterprise. Only in the case of enterprises already involved in innovative activity, the importance of product innovations in the future was noticed (Table 2).

Table 2

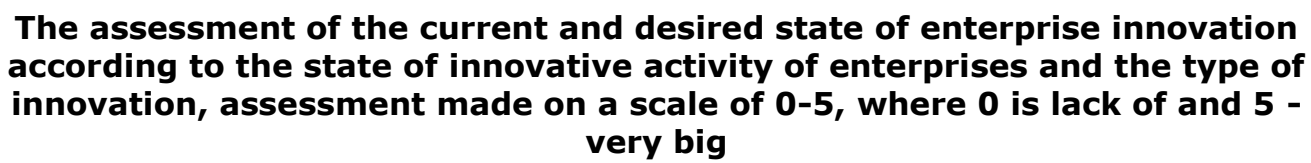

\begin{tabular}{|c|c|c|c|c|c|c|c|c|c|c|c|c|c|}
\hline \multirow{3}{*}{ No. } & \multirow{3}{*}{ Type of innovation } & \multicolumn{6}{|c|}{$\begin{array}{l}\text { The assessment of the current state in } \\
\text { enterprises }\end{array}$} & \multicolumn{6}{|c|}{ Desired state in enterprises } \\
\hline & & \multicolumn{2}{|c|}{ Total } & \multicolumn{2}{|c|}{$\begin{array}{l}\text { Introducing } \\
\text { innovations }\end{array}$} & \multicolumn{2}{|c|}{ Others } & \multicolumn{2}{|c|}{ Total } & \multicolumn{2}{|c|}{$\begin{array}{l}\text { Introducing } \\
\text { innovations }\end{array}$} & \multicolumn{2}{|c|}{ Others } \\
\hline & & $\bar{x}$ & $\mathbf{S}$ & $\bar{x}$ & $\mathbf{S}$ & $\bar{x}$ & $\mathbf{S}$ & $\bar{x}$ & $\mathbf{S}$ & $\bar{x}$ & $\mathbf{S}$ & $\bar{x}$ & $\mathbf{S}$ \\
\hline 1. & $\begin{array}{l}\text { Introducing new or } \\
\text { significantly improved } \\
\text { products or services to } \\
\text { the market }\end{array}$ & 0.66 & 1.37 & 3.17 & 1.61 & 0.16 & 0.52 & 2.37 & 1.87 & 4.04 & 0.81 & 2.04 & 1.85 \\
\hline 2. & $\begin{array}{l}\text { Introducing marketing } \\
\text { innovations }\end{array}$ & 0.48 & 1.02 & 1.54 & 1.77 & 0.27 & 0.63 & 2.22 & 1.67 & 3.25 & 1.11 & 2.02 & 1.69 \\
\hline 3. & $\begin{array}{l}\text { Introducing new or } \\
\text { significantly improved } \\
\text { processes }\end{array}$ & 0.46 & 1.10 & 2.00 & 1.82 & 0.16 & 0.52 & 2.03 & 1.81 & 3.42 & 1.02 & 1.76 & 1.82 \\
\hline 4. & $\begin{array}{l}\text { Implementation of new } \\
\text { methods regarding } \\
\text { organization }\end{array}$ & 0.27 & 0.77 & 0.63 & 1.35 & 0.20 & 0.57 & 1.27 & 1.51 & 1.50 & 1.41 & 1.22 & 1.53 \\
\hline
\end{tabular}

Source: authors' calculations based on empirical research

The non-parametric Mann-Whitney $U$ test showed that the implementation of innovations was associated with higher assessments of the economic and financial situation $(U=1057, p=0.028)$ and the company's development $(U=962, p=0.009)$. However, the statistical significance of differences was not demonstrated in the case of such features as employment $(U=1399, p=$ $0.936)$ or geographical range of the enterprise $(U=1220, p=0.181)$.

The average assessment of the economic and financial situation of the enterprise in the group of enterprises implementing innovations can be described as good, while in other entities as mediocre (the assessment was carried out in scale of 1 to 5 , with 1 being very bad and 5 very good, where the average ratings of compared groups were respectively $-\bar{x}=3.83, \mathrm{~s}=0.92$ and $\bar{x}=3.45, \mathrm{~s}=$ 0.84). Entrepreneurs introducing innovations indicated much stronger that the company developed during the analysed period, while entrepreneurs from the compared group formulated rather mediocre assessments of the organization's progress (the assessment was carried out in scale of 1 to 5 , with 1 indicating a definite lack of development and 5 a considerable development, where the average ratings of the compared groups were respectively $-\bar{x}=3.79, \mathrm{~s}=1.32, \bar{x}=3.13, \mathrm{~s}=$ 1.05).

Taking into account the sectors of enterprises' activity, the highest percentage of entities undertaking innovative activity was in the agriculture sector and services - $20.0 \%$ and $17.6 \%$, respectively. A slightly lower share was in the group of enterprises in the sector of industry and construction - $11.8 \%$.

Entrepreneurs who were active in the innovation sphere noticed a number of benefits accruing from it. The most important were increase in competitiveness of goods or services, adaption of a company's offer to the customers or contractors' expectations and improvement of a company's image. Among other effects were the acquisition of new clients, the development of human resources of an organization and the reduction of costs. It is interesting that in the examined group 
of innovative enterprises, there were clearly visible effects of innovative pro-ecological activity aimed at reducing the pressure of the organization on the natural environment (Table 3).

Table 3

The effects of innovative activity achieved in enterprises in the period 2010-2014

\begin{tabular}{|l|l|c|}
\hline No. & \multicolumn{1}{|c|}{ Effects } & Percentage \\
\hline 1. & Higher competitiveness of products/services & 71.4 \\
\hline 2. & Meeting the expectations of clients/contractors & 67.3 \\
\hline 3. & The improvement of the company's image & 61.2 \\
\hline 4. & Acquisition of new customers & 49.0 \\
\hline 5. & Improving of OHS and employees' health & 42.9 \\
\hline 6. & Improving employees' qualifications & 37.5 \\
\hline 7. & Reducing the costs & 36.7 \\
\hline 8. & Reducing the pressure of the company on the natural environment & 18.4 \\
\hline
\end{tabular}

Source: authors' calculations based on empirical research

Low innovative activity in the examined group of enterprises was associated with the observation of its barriers, mainly of a financial nature. The respondents pointed out up to three main barriers. Limiting the financing of innovative activities, both from external and internal funds, while the cost of obtaining innovation is perceived as a high, can be defined as the main limitation of innovative activity (Table 4).

Table 4

\section{Barriers most severely restricting the company's innovative activity}

\begin{tabular}{|l|l|c|c|}
\hline \multirow{2}{*}{ No. } & \multicolumn{2}{|c|}{ Barriers } & \multicolumn{2}{c|}{ Number of indications } \\
\cline { 3 - 4 } & & number & percentage \\
\hline 1. & Lack of financial resources from external sources & 66 & 24.4 \\
\hline 2. & Lack of own financial resources & 64 & 23.6 \\
\hline 3. & Too high innovation costs & 41 & 15.1 \\
\hline 4. & No demand for innovations & 26 & 9.6 \\
\hline $\mathbf{5 .}$ & Lack of qualified personnel & 16 & 5.9 \\
\hline 6. & Lack of information about markets & 10 & 3.7 \\
\hline 7. & Difficulties in finding partners & 9 & 3.3 \\
\hline $\mathbf{8 .}$ & Lack of information about technology & 6 & 2.2 \\
\hline $\mathbf{9 .}$ & There are no barriers & 33 & 12.2 \\
\hline \multicolumn{2}{|l}{ Total } & $\mathbf{2 7 1}$ & $\mathbf{1 0 0 . 0}$ \\
\hline
\end{tabular}

Source: authors' calculations based on empirical research

However, at the same time, quite a large group of entrepreneurs not noticing the existence of innovation activity's barriers is drawing the attention. It is also interesting that in the group of enterprises implementing innovations, $12.5 \%$ of entrepreneurs reported lack of barriers, whereas in the remaining ones $-24.4 \%$.

\section{Conclusions}

The undertaken research on the innovative activity of enterprises operating in the peripheral region indicate its limited scope and to a large extent they coincide with the results of researches on the innovation of enterprises undertaken in other peripheral European regions. The researches allowed affirmative verification of the hypothesis about the existence of a small group of enterprises on the examined area which are focused on development, active in the sphere of introducing innovations, aware of the need to implement them and capable of overcoming 
numerous barriers in this process. In particular, the following conclusions can be drawn from the undertaken research:

1) Despite the generally low level of innovative activity, mainly of productive character, a much larger group of examined enterprises declared their willingness to introduce innovations; however, the noticeable declared increase of importance of innovative activity in the future concerned those enterprises that were already involved in innovative activities during the research period. These enterprises noticed the need to implement innovations.

2) In the examined group of enterprises, it is possible to indicate pro-developmentally oriented entities which in a further perspective are able to have a stronger, positive impact on local development processes. Undertaking innovative activity was connected with achieving good economic and financial results and showing a considerable development and strengthening the competitive position of the company over the research period.

3) Despite the low pro-innovation activity, a significant group of examined entrepreneurs does not hold the view that it deviates from competitors in this area. A significant group of enterprises which do not undertake innovative activities, implement the existing models of organization's functioning in relatively stable competitive environment, simultaneously not noticing the need for radical changes and the barriers of innovative activity. Other groups do not appear to be capable of introducing changes of developmental nature due to the difficult economic situation and high costs of innovative activities.

4) Barriers of innovative activity are not noticed by quite a large group of respondents $(22.4 \%)$. Restrictions of innovations are more often noticed by entrepreneurs active in the sphere of implementing innovations who had to face the practice of introducing changes. The main barriers limiting the innovative activity of the examined enterprises include financial barriers. Barriers related to the limited access to knowledge in the innovation process in comparison with financial barriers are not very important.

\section{Bibliography}

1. Araujo, L., Silva, S., Teixeira, A. (2013, March). Knowledge Spillovers and Economic Performance of Firms Located in Depressed Areas: Does Geographical Proximity Matter? In Proceedings of the 17th APDR Workshop Firm Performance and Growth. A Regional, Institutional and Policy Perspective, Aveiro: University of Aveiro, 185-208.

2. Isaksen, A., Karlsen, J. (2016). Chapter 16: Innovation in Peripheral Regions in: Shearmur, R., Carrincazeaux, C., Doloreux, D. (Eds.). Handbook on the Geographies of Innovation. Edward Elgar Publishing.

3. Boschma, R. A. (2005). Proximity and Innovation: a Critical Assessment, Regional Studies, 39, 61-74.

4. Copus, A., Skuras, D., Tsegenidi, K. (2008). Innovation and Peripherality: An Empirical Comparative Study of SMEs in six European Union Member Countries. Economic Geography, 84(1), 51-82.

5. Coronado, D., Acosta, M., Fernandez, A. (2008). Attitudes to Innovation in Peripheral Economic Regions. Research Policy, 37(6), 1009-1021.

6. De Noronha Vaz, M. T., Cesario, M., Fernandes, S. (2006). Interaction Between Innovation in Small Firms and Their Environments: An Exploratory Study. European Planning Studies, 14(1), 95-117.

7. Drejer, I., Vinding, A. L. (2005). Location and collaboration: Manufacturing firms' use of knowledge intensive services in product innovation. European Planning Studies, 13(6), 879-898.

8. Fitjar, R. D., Rodríguez-Pose, A. (2011). Innovating in the Periphery: Firms, Values and Innovation in Southwest Norway. European Planning Studies, 19(4), 555-574.

9. Grillitsch, M., Nilsson, M. (2014), Innovation in Peripheral regions: Do collaborations Compensate for a Lack of Local Knowledge Spillovers?, No 2014/33, Papers in Innovation Studies, Lund University, CIRCLE - Center for Innovation, Research and Competences in the Learning Economy, https://EconPapers.repec.org/RePEc:hhs:lucirc:2014_033.

10. Guzal-Dec, D., Zwolinska-Ligaj, M. (2017a). The Role of Local Action Groups in the Process of Multifunctional Development of a Peripheral Region. A Case Study of the Region of Lublin, Poland. Wies $\mathrm{i}$ Rolnictwo 3 (176), doi: 10.7366/wir032017/05. 
11. Guzal-Dec, D., Zwolinska-Ligaj, M. (2017b, January). Local Action Groups as New Organisations in Rural Development. An Exapmle of the Lublin Region (Poland). In Economic Science for Rural Development Conference Proceedings (No. 44), 58-68.

12. Innovation Systems and the Periphery, FINAL REPORT, Nordic Innovation Centre, January 2005, https://www.rha.is/static/files/Rannsoknir/2005/ISP-final-report2.pdf

13. Muller, E. (1999). There Is No Territorial Fatality!(Or How Innovation Interactions Between KIBS and SMEs May Modify the Development Patterns of Peripheral Regions) (No. R3/1999). Arbeitspapiere Unternehmen und Region.

14. North, D., Smallbone, D. (2000). Innovative Activity in SMEs and Rural Economic Development: Some Evidence From England. European Planning Studies, 8(1), 87-106.

15. Oslo Manual. Guidelines for Collecting and Interpreting Innovation Data, OECD/Eurostat, Paris 2005.

16. Ploszaj, A. (2012). Instytucje wsparcia biznesu i promowania innowacji w wojewodztwie lubelskim (Institutions Supporting Business and Promoting Innovation in the Lublin Voivodeship).

17. Rodríguez - Pose, A. (1999). Innovation Prone and Innovation Averse Societies: Economic Performance in Europe. Growth and change, 30(1), 75-105.

18. Smallbone, D., North, D., Kalantaridis, C. (1999). Adapting To Peripherality: a Study of Small Rural Manufacturing Firms in Northern England. Entrepreneurship \& Regional Development, 11(2), 109-127.

19. Todtling, F., Lehner, P., Kaufmann, A. (2009). Do Different Types of Innovation Rely on Specific Kinds of Knowledge Interactions? Technovation, 29(1), 59-71.

20. Varis, M., Littunen, H. (2012). SMEs and Their Peripheral Innovation Environment: Reflections From a Finnish Case. European Planning Studies, 20(4), 547-582.

21. Virkkala, S. (2007). Innovation and Networking in Peripheral Areas - a Case Study of Emergence and Change in Rural Manufacturing, European Planning Studies, 15(4), 511-529.

22. Zwolinska-Ligaj, M. A., Adamowicz, M. (2017, January). The Activity of Local Self-Governments In the Area of Creating Local Innovation (Based On the Example of Lublin counties, Poland). In Economic Science for Rural Development Conference Proceedings (No. 44), 226-235. 